\title{
Pharmacognostic standardization of a well known edible mushroom, Volvariella volvacea
}

\author{
Krishnendu Acharya ${ }^{*}$, Sandipta Ghosh, Ipshita Kundu \\ Molecular and Applied Mycology and Plant Pathology Laboratory, Department of Botany, University of Calcutta, 35, Ballygunge Circular Road, \\ Kolkata 700019, West Bengal, India.
}

\begin{tabular}{|c|c|}
\hline ARTICLE INFO & ABSTRACT \\
\hline $\begin{array}{l}\text { Article history: } \\
\text { Received on: } 06 / 09 / 2016 \\
\text { Revised on: } 25 / 09 / 2016 \\
\text { Accepted on: } 17 / 10 / 2016 \\
\text { Available online: } 29 / 11 / 2016\end{array}$ & $\begin{array}{l}\text { From ancient times, Volvariella volvacea has been recognized as a dietary addition in many Asian and European } \\
\text { countries. Clinical evaluations have also revealed that the fruit body contains a great diversity of } \\
\text { pharmacologically active constituents that posses remarkable medicinal activities. However pharmacognostic } \\
\text { studies of the mushroom have not been carried out so far. So the present study was conducted with a view to } \\
\text { establish a pharmacognostic standard of the dried powder of } V \text {. volvacea. Study was executed on the basis of }\end{array}$ \\
\hline $\begin{array}{l}\text { Key words: } \\
\text { Antioxidant property, HPLC, } \\
\text { Medicinal edible mushroom, } \\
\text { Microscopic characters, } \\
\text { Pharmacognostic } \\
\text { standardization. }\end{array}$ & $\begin{array}{l}\text { of the dried powder was also conducted using different chemical reagents. On the other hand, a fresh methanol } \\
\text { soluble extract was prepared and prelimiminary screening of phytochemicals revealed the presence of phenols, } \\
\text { flavonoids, ascorbic acid, } \beta \text {-carotene and lycopene. In addition, HPLC profile was recorded and results showed } \\
\text { existence of } 12 \text { peaks as detected at } 278 \mathrm{~nm} \text { which might be of phenolic compounds. Furthermore, DPPH radical } \\
\left.\text { scavenging activity (EC } \mathrm{EC}_{50}-0.12 \mathrm{mg} / \mathrm{ml}\right) \text { and total antioxidant capacity }(23.75 \pm 1.25 \mu \mathrm{g} \text { ascorbic acid } \\
\text { equivalent } / \mathrm{mg} \text { of extract) were conducted to evaluate antioxidant potentiality of the methanol extract. All these } \\
\text { above mentioned standards developed from this study will help in maintaining quality and purity as well as } \\
\text { ascertain the identity and authenticity of dried powder of } V \text {. volvacea. }\end{array}$ \\
\hline
\end{tabular}

\section{INTRODUCTION}

In modern civilizations, natural products are becoming an effective alternative to the toxic chemicals used in preparation of synthetic medicine. Recently, many pharmaceutical companies have started paying their attention towards the exploitation of natural products in medicine formulation. The outputs are quite successful as because the bioactive compounds from natural resources are considered to be safe with no side-effects. But the main hinderance in acceptance of alternative medicine is the lack of standard documentation (Dahanurkar et al., 2000). Thus, there is a need for quality control standardization of these products which not only helps in proper identification but also in

\footnotetext{
* Corresponding Author

Krishnendu Acharya, Molecular and Applied Mycology and Plant Pathology Laboratory, Department of Botany, University of Calcutta, 35, Ballygunge Circular Road, Kolkata 700019, West Bengal, India E-mail: krish_paper@yahoo.com
}

authentication of genuine material (Kushwaha et al., 2010). However no single method can provide the absolute result. The best solution is compilation of several different parameters of pharmacognosy including qualitative as well as quantitative measure to get a detailed and multidimensional view of the product. Nowadays researchers have relied more on the therapeutic values of mushrooms.

Different mushroom metabolites and active components have shown strong medicinal prospects (Khatua et al., 2013; Mitra et al., 2016; Chatterjee et al., 2014; Chatterjee et al., 2016; Mallick et al., 2014; Mallick et al., 2015; Nandi et al., 2014; Nandi et al., 2013). Volvariella volvacea is one such potential mushroom, commonly known as paddy straw mushroom belongs to the family Pluteaceae (Order: Agaricales).

It is a tropical cosmopolitan edible macrofungi and also cultivated commercially throughout the Southeast Asia. This mushroom is considered a delicacy in Asian cuisines because of its delightful taste and flavor. 
Besides this, the medicinal impact of this mushroom has been scientifically evaluated by a number of scientists around the globe establishing its antioxidative (Rai and Acharya, 2012, Sudha et al., 2008, Ramkumar et al., 2012; Tripathy et al., 2016), antimicrobial (Perera et al., 2001; Ayodele and Idoko, 2011), hepatoprotective (Kalava et al., 2012a; Kalava et al., 2012b; Acharya et al., 2012), anticancer (Wu et al., 2011; Maiti et al., 2008) and immunomodulatory (Jeurink et al., 2008; Hao-Chi et al., 1997) properties. Additionally, a variety of biologically active compounds have been isolated from this mushroom (Hao-chi et al., 1997).

As the demand of this mushroom is increasing day by day for its immense medicinal importance, a strong pharmacognostic profiling is of utmost needed. Therefore, the main objective of the present work is to establish the pharmacognostic parameters of this mushroom using standard methods, which could be helpful in preparation of a monograph for the proper identification of the mushroom.

\section{MATERIALS AND METHODS}

\section{Mushroom materials}

Basidiocarps of $V$. volvacea were collected during the rainy season from coastal villages of West Bengal. Identification and authentication of the basidiocarp was done using standard literature (Shaffer 1997, Dutta et al. 2011) and the voucher specimen present in CUH herbarium. A representative specimen (CUH AM036) was deposited in the same herbarium for future reference as per the method by Pradhan et al., 2015. For powder analysis basidiocarps were first dried by field drier at $40^{\circ} \mathrm{C}$ for overnight, then pulverized to make them crispy using electric blender and this coarse powder was sieved into a fine powder by using a160 mesh. Then the finely sieved powder was stored in an airtight container for future use.

\section{Microscopic and organoleptic characterization of powdered basidiocarps}

Microscopic features were obtained from dried powder of the basidiocarps in 5\% $\mathrm{KOH}$, Melzer's reagent, and Congo red. The slide was then examined under Carl Zeiss AX10 Imager A1 phase contrast microscope and images were captured with a digital camera at desired magnifications. Several other features like colour, odour, taste, and nature of dried powder were also evaluated.

\section{Fluorescence analysis}

Fluorescence study of dried sieved powder was performed as per standard procedure (2007). A small quantity of sieved powder was placed on a grease free slide and treated with 16 different chemical agents and mixed properly by gentle tilting the slide. Then the slide was placed inside the UV viewer chamber and exposed to visible, short $(254 \mathrm{~nm})$ and long $(365 \mathrm{~nm})$ ultraviolet light to study their fluorescence behavior.

\section{Preparation of methanolic extract}

$5 \mathrm{~g}$ of pulverized dried powder was soaked in $100 \mathrm{ml}$ methanol for $72 \mathrm{~h}$ before extraction. Thereafter, it was filtered through Whatman No. 1 filter paper. The filtrate was concentrated under reduced pressure at $80^{\circ} \mathrm{C}$ using rotary evaporator and preserved in refrigerator at $4^{\circ} \mathrm{C}$ in a dark bottle for further use. Extractive value was also recorded.

\section{Quantitative estimation of mycochemicals}

Methanolic extract was subjected for quantitative estimation of mycochemicals such as phenol, flavonoids, ascorbic acid, $\beta$ carotene and lycopene. The content of total phenolic compounds in extract was estimated using Folin-Ciocalteu reagent and gallic acid as standard. The results were expressed as $\mu \mathrm{g}$ of gallic acid equivalents per mg of dry extract. Total flavonoid content was determined using aluminium nitrate and potassium acetate. Quercetin $(5-20 \mu \mathrm{g} / \mathrm{ml})$ was used to calculate the standard curve.

The results were expressed as $\mu \mathrm{g}$ of quercetin equivalents per mg of dry extract. $\beta$ - carotene and lycopene were estimated by measuring absorbance at 453, 505 and $663 \mathrm{~nm}$. Ascorbic acid was determined by titration against 2, 6-dichlorophenol indophenol dye (Khatua et al., 2015).

\section{High performance liquid chromatographic (HPLC) profile of methanolic extract}

The extract was filtered through $0.2 \mu \mathrm{m}$ filter paper and $20 \mu$ filtrate was loaded on the HPLC system (Agilent, USA). Separation was achieved on an Agilent Eclipse Plus C18 column $(100 \mathrm{~mm} \times 4.6 \mathrm{~mm}, 3.5 \mu \mathrm{m})$ using a flow rate of $0.8 \mathrm{ml} / \mathrm{min}$ at $25^{\circ} \mathrm{C}$ using 11 standards. The mobile phase consisted of eluent $\mathrm{A}$ (acetonitrile) and eluent B (aqueous phosphoric acid solution, $0.1 \% \mathrm{v} / \mathrm{v})$. A gradient program was used for elution: $0-2 \mathrm{~min}, 5 \%$ A; 2-5 min, $15 \%$ A; 5-10 min, 40\% A; 10-15 min, 60\% A; 15-18 min, $90 \%$ A. The absorbance of sample solution was measured at $280 \mathrm{~nm}$ (Khatua et al., 2015).

\section{DPPH radical scavenging activity}

A solution of DPPH was freshly prepared by dissolving DPPH dye in required volume of methanol (about $0.1 \mathrm{mM}$ ). $2 \mathrm{ml}$ reaction mixture consisted of freshly prepared methanol solution of DPPH $(0.1 \mathrm{mM})$ and various concentrations of extract. After 30 minutes of incubation in dark at room temperature absorbance was measured at $517 \mathrm{~nm}$ against blank (Shimada et al., 1992). The percentage inhibition of radicals was calculated using the following formula:

$$
\% \text { inhibition }=\left(\mathrm{A}_{\text {control }}-\mathrm{A}_{\text {sample }}\right) \times 100 / \mathrm{A}_{\text {control }}
$$

Where $A_{\text {control }}$ is the absorbance of DPPH solution without extract and $\mathrm{A}_{\text {sample }}$ is the absorbance of sample with DPPH solution. The $\mathrm{EC}_{50}$ value was reported as the effective concentration at which DPPH radicals were scavenged by $50 \%$. Ascorbic acid was used for comparison. All tests were performed at least in triplicate, and graphs were plotted using the average of three determinations. 


\section{Total antioxidant assay for methanolic extract}

The reaction mixture consisted of $0.3 \mathrm{ml}$ sample solution and $3 \mathrm{ml}$ of reagent solution $(0.6 \mathrm{M}$ sulphuric acid, $28 \mathrm{mM}$ sodium sulphate and $4 \mathrm{mM}$ ammonium molybdate), according to the method by Prieto et al., 1999. Tubes were capped and incubated at $95^{\circ} \mathrm{C}$ for $90 \mathrm{~min}$. Samples were cooled at room temperature and absorbance was measured at $695 \mathrm{~nm}$ against blank. Concentrations of ascorbic acid (1-30 $\mu \mathrm{g} / \mathrm{ml})$ were used to obtain a standard curve. Total antioxidant activity was expressed as the number of equivalents of ascorbic acid.

\section{Statistical analysis}

All assays were carried out in triplicate. The results are expressed as mean values and standard deviation (SD). Results were compared by means of a Student's $t$ test to determine the significant difference among samples. The analysis was carried out using Microsoft ${ }^{\circledR}$ Office Excel (Microsoft ${ }^{\circledR}$, USA), where values of $\mathrm{p} \leq 0.05$ were considered as statistically significant.

\section{RESULTS AND DISCUSSION}

Authentication of natural material is a crucial prerequisite step before using in research field or for medicinal purpose. Therefore, in this study we have performed the different parameters of pharmacognostic investigation to standardize this macrofungus to some extent. Organoleptic characterization of dried powder is considered as an important part of pharmacognostic standardization. The crude sieved powder was light brown in colour, salty taste without any significant odour and powdery in texture. The dried sieved powder of $V$. volvacea under microscopic investigation with $5 \% \mathrm{KOH}$ and Congo red showed following characters (Figure 1): Several fragmented thin-walled hyphae lacking clamp connection, spores ovoid to ellipsoid (5.13 $\mu \mathrm{m} \times 2.38 \mu \mathrm{m})$ ochraceous salmon, smooth with thickened wall and guttulate contents, basidia $(14.08 \mu \mathrm{m}-4.95 \mu \mathrm{m}$ x $2.61 \mu \mathrm{m}$ $1.24 \mu \mathrm{m})$ clavate, tetrasterigmatic. Melzer's reaction showed negative result which indicates that the spores are non-amyloid in nature.

Fluorescence analysis is also an important tool for qualitative assessment of crude drug and it provides an idea about their chemical nature (Sonibare and Olatubosun, 2015, Bhattacharya and Zaman, 2009). If substance themselves do not give fluorescence; they may often be converted into fluorescent derivatives or decomposition products by applying different chemical reagents. This distinguishing character is useful in identification of authentic samples and recognizing adulterates. The fluorescence characteristics of dried powder of $V$. volvacea are summarized in Table 1.

Freshly prepared methanolic extract was subjected for organoleptic characterization and quantitative estimation of phytochemicals. The fraction was brownish in colour, sticky in nature with extractive value of $15 \pm 2.3 \%$.
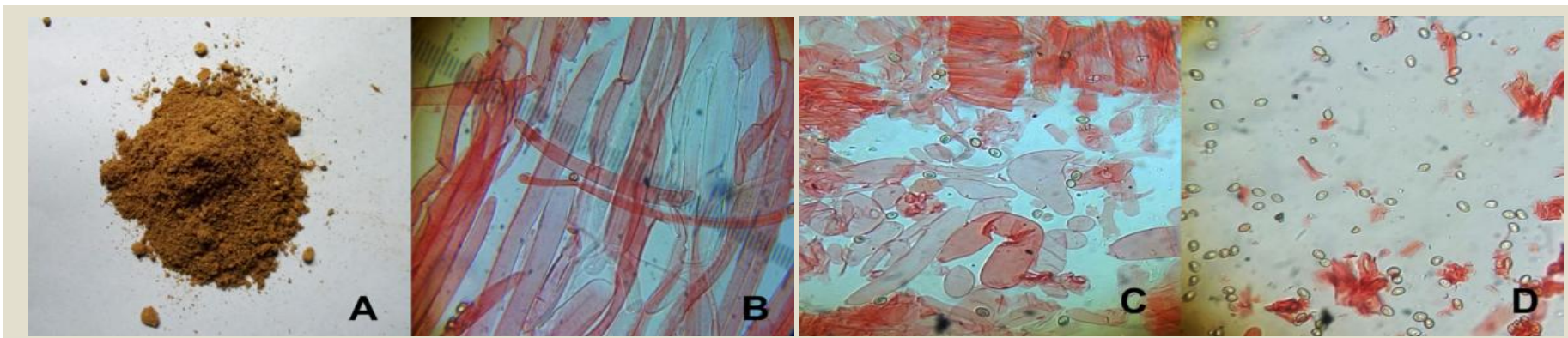

Fig. 1: A) Sieved powder of Volvariella volvacea. Microscopic characterization: B) Hyphae C) Fragmented hyphae, basidia and spores D) Spores.

Table 1: Fluorescence profile of dried powder of Volvariella volvaceae.

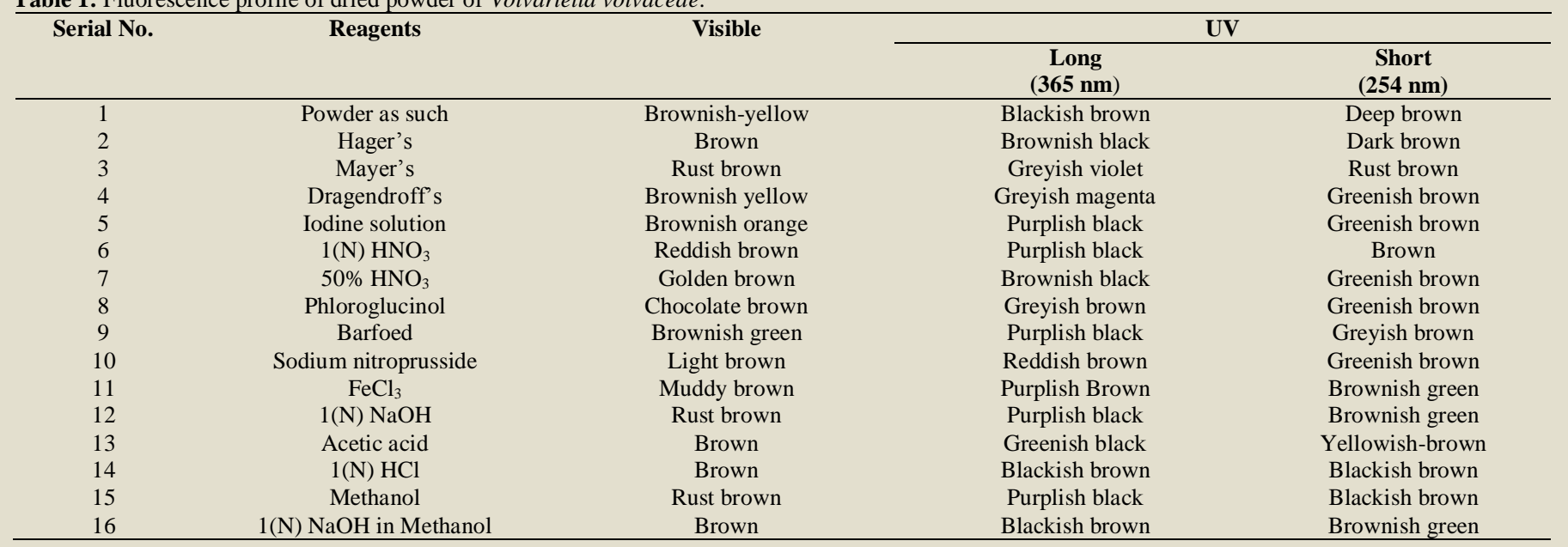


Quantification of different signature phytochemicals present in the methanolic extract of $V$. volvacea showed three major antioxidant compounds that are present in the following order: ascorbic acid $>$ phenol $>$ flavonoid. $\beta$ carotene and lycopene were found in negligible amount (Table 2).

Table 2: Mycochemical estimation of methanolic extract of Volvariella volvaceae.

\begin{tabular}{lc}
\hline Mycochemical constituents & Amount \\
\hline Total phenols $(\mu \mathrm{g} \mathrm{GAE} / \mathrm{mg}$ of extract) & $8.75 \pm 0.44$ \\
Total flavonoids $(\mu \mathrm{g} \mathrm{QE} / \mathrm{mg}$ of extract) & $1.56 \pm 0.22$ \\
$\beta$ carotene $(\mu \mathrm{g} / \mathrm{mg}$ of extract) & $0.286 \pm 0.022$ \\
Lycopene $(\mu \mathrm{g} / \mathrm{mg}$ of extract) & $0.231 \pm 0.021$ \\
Ascorbic acid $(\mu \mathrm{g} / \mathrm{mg}$ of extract) & $9.7125 \pm 0.528$ \\
\hline
\end{tabular}

In comparison with already published reports of mushrooms such as Griffola frondosa $(0.37 \mu \mathrm{g} / \mathrm{mg}$ of extract) (Acharya et al., 2015a), Ganoderma lucidum $(2.77 \mu \mathrm{g} / \mathrm{mg}$ of extract) (Acharya et al., 2015b), Macrocybe crassa $(1.81 \mu \mathrm{g} / \mathrm{mg}$ of extract) (Acharya et al., 2015c), Lentinula edodes $(3.96 \mu \mathrm{g} / \mathrm{mg}$ of extract) (Acharya et al., 2015d), Pleurotus ostreatus $(11.1 \mu \mathrm{g} / \mathrm{mg}$ of extract) (Acharya et al., 2016a), and Laetiporus sulphureus (2 $\mu \mathrm{g} / \mathrm{mg}$ of extract) (Acharya et al., 2016b), ascorbic acid content of this mushroom was found to be the highest one. According to earlier reports, besides fruits and vegetables, mushrooms are also considered as a huge resource antioxidant compounds. As a part of this category, ascorbic acid is one of the strong water soluble antioxidant.

Chromatographic study also can be categorized as a part of chemical fingerprint. The HPLC fingerprint showed a characteristic fingerprint profile that serves as markers for quality control standardization of the crude drug. Qualitative analysis of the chromatogram revealed existence of 12 peaks with two mobile phase peaks as presented in Figure $2 . R_{f}$ value of each corresponding peak helps to identify the chemical compounds present in the drug. $\quad R_{f}$ value along with area of each corresponding peak are given in the Table 3 . In order to investigate the antioxidant activity, the methanolic fraction was subjected for two different in vitro assays. DPPH radical scavenging assay constitutes the most simple and widely used method to evaluate antioxidant activities in comparatively short time than others. Stable DPPH radical shows absorption maxima at $517 \mathrm{~nm}$. Antioxidant compounds present in the extract decreases its absorbance due to their hydrogen donating ability. It can be visualized by discoloration of purple colored solution to yellow. As shown in Figure 3, scavenging effect of methanolic extract of $V$. volvacea increased in a concentration dependent manner. $\mathrm{EC}_{50}$ value of the methanol extract was $0.12 \mathrm{mg} / \mathrm{ml}$. Our result also coincides with the earlier works which proves that the methanolic extract of different mushrooms have strong antioxidant capacity (Khatua et al., 2013).

Another assay was also carried out to test antioxidant potentiality of the methanolic extract termed as total antioxidant capacity assay using phosphomolybdenum method. The theory is based on the reduction of Mo (IV) to Mo (V) and formation of green phosphate / Mo (V) complex with characteristic absorption at $695 \mathrm{~nm}$. The total antioxidant capacity was determined using linear regression equation expressed as the number of equivalent of ascorbic acid which was found to be $23.75 \pm 1.25$ ascorbic acid equivalent (AAE) per mg of extract. Therefore high content of ascorbic acid can justify the good antioxidant potentiality of the extract.

Table 3: HPLC profile of methanol extract of Volvariella volvacea at $278 \mathrm{~nm}$

\begin{tabular}{ccc}
\hline Peak no. & Retention time (min) & Area (AU) \\
\hline 1 & 4.949 & 724.45807 \\
2 & 5.207 & 2581.14868 \\
3 & 6.165 & 155.25165 \\
4 & 8.688 & 376.34503 \\
5 & 10.037 & 314.59995 \\
6 & 10.354 & 128.91489 \\
7 & 10.504 & 259.02283 \\
8 & 10.834 & 392.47763 \\
9 & 11.282 & 582.46271 \\
10 & 12.355 & 18.17178 \\
11 & 12.597 & 10.77141 \\
12 & 15.806 & 216.32178 \\
\hline
\end{tabular}

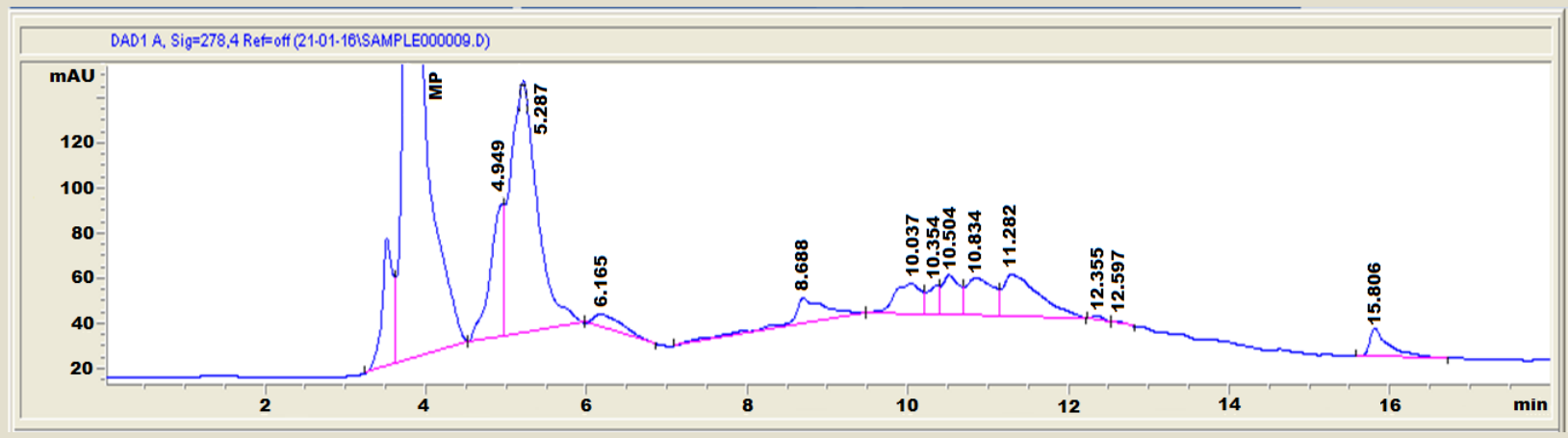

Fig. 2: Enlarged HPLC chromatogram of methanol extract from Volvariella volvacea at $278 \mathrm{~nm}$. 


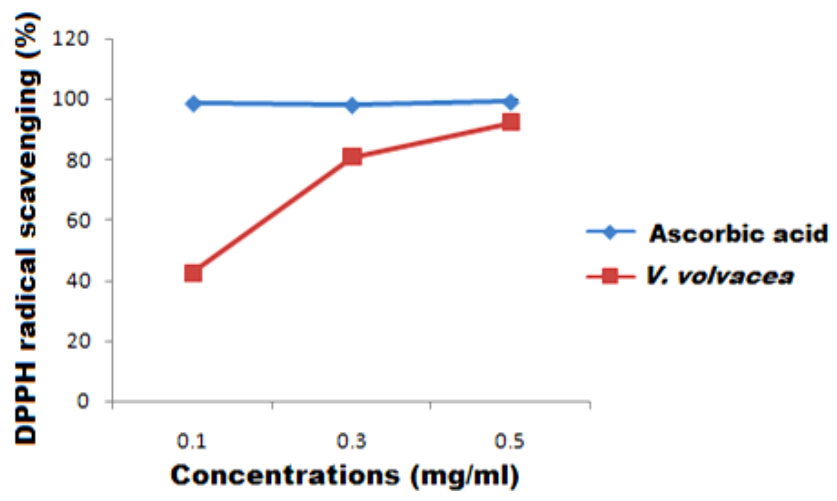

Fig. 3: DPPH radical scavenging activity of methanol extract from Volvariella volvacea.

\section{CONCLUSION}

The present study provides pharmacognostic standards of $V$. volvacea powder with the help of modern sophisticated techniques and relevant parameters. Different pharmacological parameters including microscopy, organoleptic, mycochemical quantification as well as chromatographic profiling were reported for the first time for this mushroom. All these aggregated data will help to authenticate the crude powder before processing for drug formulations and also to identify the genuine species.

\section{ACKNOWLEDGEMENT}

Financial support and sponsorship: Nil.

Conflict of Interests: There are no conflicts of interest.

\section{REFERENCES}

Acharya K, Bera I, Khatua S, Rai M. Pharmacognostic standardization of Grifola frondosa: A well-studied medicinal mushroom. Pharm Lett, 2015; 7: 72-78.

Acharya K, Bera M, Tarafder E, Dasgupta A. Pharmacognostic standardization of Ganoderma lucidum: A commercially explored medicinal mushroom. Pharm Lett, 2015; 7: 175-181.

Acharya K, Chatterjee S, Biswas G, Chatterjee A, Saha GK. Hepatoprotective effect of a wild edible mushroom on carbon tetrachloride-induced hepatotoxicity in mice. Int J Pharm Pharm Sci, 2012; 4: 285-288.

Acharya K, Ghosh S, Ghosal S. Pharmacognostic standardization of a widely explored medicinal mushroom, Pleurotus ostreatus. Pharm Lett, 2016; 8: 66-72.

Acharya K, Ghosh S, Khatua S, Mitra P. Pharmacognostic standardization and antioxidant capacity of an edible mushroom Laetiporus sulphureus. J Verbr Lebensm, 2016; 11: 33-42.

Acharya K, Khatua S, Sahid S. Pharmacognostic standardization of Macrocybe crassa: an imminent medicinal mushroom. Res J Pharm Technol, 2015; 8: 860-866.

Acharya K, Mukherjee S, Mitra P. Pharmacognostic standardisation of Lentinula edodes: A widely explored medicinal mushroom. Int J Pharmacognosy Phytochem Res, 2015; 7: 866-872

Ayodele SM, Idoko ME. Antimicrobial activities of four wild edible mushrooms in Nigeria. IJSN, 2011; 2: 55-58.

Bhattacharya S, Zaman MK. Pharmacognostical evaluation of Zanthoxylum nitidum bark. Int J Pharm Tech Res, 2009; 1: 292-298.
Chatterjee A, Acharya K. Include mushroom in daily diet-A strategy for better hepatic health. Food Res Int, 2016; 32:68-97.

Chatterjee S, Biswas G, Chandra S, Saha GK, Acharya K. Chemopreventive effect of Tricholoma giganteum against benzo[a]pyreneinduced forestomach cancer in Swiss albino mice. Int J Pharmaceut Sci Rev Res. 2014; 26: 189-196.

Dahanurkar SA, Kulkarni RA, Rege NN. Pharmacology of medicinal plants and natural products. Ind J Pharmacol, 2000; 32: 81-118.

Dutta AK, Pradhan P, Roy A, Acharya K. Volvariella of West Bengal, India I. Researcher, 2011; 3: 13-17.

Hao-Chi HSU, Chyong-Ing HSU, Rong-Hwa LIN, Chian-Liang KAO, Jung-Yaw LIN. Fip-vvo, a new fungal immunomodulatory protein isolated from Volvariella volvacea. Biochem J, 1997; 323: 557-565.

Indian Pharmacopoeia Commission (2007) Indian pharmacopoeia, vol I. Government of India, New Delhi

Jeurink PV, Noguera CL, Savelkoul HFJ, Wichers HJ. Immunomodulatory capacity of fungal proteins on the cytokine production of human peripheral blood mononuclear cells. Int Immunopharmacol, 2008; 8: 1124-1133.

Kalava SV, Menon SG. Protective efficacy of the aqueous extract of Volvariella volvacea (Bulliard Ex Fries) Singer against ethanol induced hepatic damage. Int J Pharm Pharm Sci, 2012; 4: 527-532.

Kalava SV, Menon SG. Protective efficacy of the extract of Volvariella volvacea (bulliard ex fries) singer. against carbontetrachloride induced hepatic injury. IJPSR, 2012; 3: 2849-2856.

Khatua S, Dutta AK, Acharya K. Russula senecis: a delicacy among the tribes of West Bengal. PeerJ, 2015; 3:e810. doi:10.7717/peerj.810

Khatua S, Paul S, Acharya K. Mushroom as the potential source of new generation of antioxidant: A review. Res J Pharm Tech, 2013; $6: 496-505$

Kushwaha SKS, Kushwaha N, Maurya N, Rai AK. Role of Markers in the Standardization of Herbal Drugs: A Review. Arch Appl Sci Res, 2010; 2: 225-229.

Maiti S, Bhutia SK, Mallick SK, Kumar A, Khadgi N, Maiti TK. Antiproliferative and immunostimulatory protein fraction from edible mushrooms. Environ Toxicol Pharmacol, 2008; 26: 187-191.

Mallick S, Dey S, Mandal S, Dutta A, Mukherjee D, Biswas G et al. A novel triterpene from Astraeus hygrometricus induces reactive oxygen species leading to death in Leishmania donovani. Future Microbiol, 2015; 10:763-89.

Mallick S, Dutta A, Dey S, Ghosh J, Mukherjee D, Sultana SS et al. Selective inhibition of Leishmania donovani by active extracts of wild mushrooms used by the tribal population of India: An in vitro exploration for new leads against parasitic protozoans. Exp Parasitol, 2014; 138: 9-17.

Mitra P, Mandal NC, Roy A, Acharya K. Phytochemical Study and antioxidative property of ethanolic extract from Termitomyces clypeatus. J App Pharm Sci, 2016; 6: 120-124.

Nandi AK, Samanta S, Maity S, Sen IK, Khatua S, Devi KSP, Acharya K, Maiti TK, Islam SS. Antioxidant and immunostimulant $\beta$ glucan from edible mushroom Russula albonigra (Krombh.) Fr Carbohydr Polym, 2014; 99: 774-782.

Nandi AK, Samanta S, Sen IK, Devi KSP, Maiti TK, Acharya $\mathrm{K}$, SS Islam. Structural elucidation of an immunoenhancing heteroglycan isolated from Russula albonigra (Krombh.) Fr. Carbohydr Polym, 2013; 94: $918-926$

Perera WASW, Abeytunga DTU, Wijesundera RLC. Antibacterial activities of Volvariella volvaceae. J Natn Sci Foundation Sri Lanka, 2001; 29: 61-68.

Pradhan P, Dutta AK, Acharya K. A low cost long term preservation of macromycetes for fungarium. Protoc Exch, 2015; doi:10.1038/protex.2015.026.

Prieto P, Pineda M, Aguilar M. Spectrophotometric quantitation of antioxidant capacity through the formation of phosphomolybdenum complex: specific application to the determination of vitamin E. Anal Biochem, 1999; 269: 334-337. 
Rai M, Acharya K. Evaluation of antioxidant and nitric oxide synthase activation properties of Volvariella volvacea. Int J Pharm Pharm Sci, 2012; 4: 460-463.

Ramkumar L, Ramanathan T, Johnprabagaran J. Evaluation of nutrients, trace metals and antioxidant activity in Volvariella volvacea (Bull. Ex. Fr.) Sing. Emir J Food Agric, 2012; 24: 113-119.

Shaffer RL. Volvariella in North America. Mycologia, 1997; 49: 545-579.

Shimada K, Fujikawa K, Yahara K, Nakamura T. Antioxidative properties of Xanthan on the autoxidation of soybean oil in cyclodextrin emulsion. J Agric Food Chem, 1992; 40: 945-948.

Sonibare MA, Olatubosun OV. Pharmacognostic and free radical scavenging evaluation of Cyathula prostata (Blume) L. Phrmacogn J, 2015; 7: 107-116.

Sudha A, Lakshmanan P, Kalaiselvan B. Antioxidant properties of paddy straw mushroom (Volvariella volvacea (Bull. ex Fr.)) Sing. IJAAR, 2008; 3: 9-16.

Tripathy SS, Rajoriya A, Mahapatra A, Gupta N. Biochemical and antioxidant properties of wild edible mushrooms used for food by tribal of eastern India. Int J Pharm Pharm Sci, 2016; 8: 194-199.

Wu JY, Chen CH, Chang WH, Chung KT, Liu YW, Lu FJ, Chen $\mathrm{CH}$. Anticancer effects of protein extracts from Calvatia lilacina, Pleurotus ostreatus and Volvariella volvacea. eCAM, Volume 2011, Article ID 982368, 10 pages doi:10.1093/ecam/neq057

\section{How to cite this article:}

Acharya K, Ghosh S, Kundu I. Pharmacognostic standardization of a well known edible mushroom, Volvariella volvacea. J App Pharm Sci, 2016; 6 (11): 185-190. 